\title{
The Difference Analysis between Demographic Variables and Personal Attributes - The Case of Internal Auditors in Taiwan
}

\author{
Li-Jia Chiu and Neng-Tang Norman Huang \\ Department of Technology Application and Human Resource Development, \\ National Taiwan Normal University, Taiwan \\ chiu.judy1188@gmail.com, nthuang@ntnu.edu.tw
}

\begin{abstract}
Internal control plays a pivotal role in enhancing security operations and quality control in an organization. From the perspective of management, internal auditors work for ensuring effective operations and improving performance for all the management systems within the organization. They bear great responsibility and play a key role. This study aimed to explore the internal audit staff demographic variables of personality traits differences. This research selected samples of the internal auditors from domestic companies, i.e. members of the Institute of Internal Auditors, in Taipei, Hsinchu, Taichung, and Kaohsiung. A total of 567 questionnaires are issued and the number of valid questionnaires is 272 .
\end{abstract}

Keywords: Internal auditors, personal attributes, demographic variables.

\section{Introduction}

\subsection{Background}

The major business scandals occurring in the recent years, such as the Eron case in 2001, which filed for bankruptcy, and the WorldCom case in 2002, whose CEO, Bernard Ebbers, was forced to resign due to his loans to the company in personal name, have drawn worldwide attention to corporate governance, and revealed the importance of the roles and functions of internal auditors.

The Five Factors Model (FFM) of the personality traits is the most influential model in personality theory. The perspective of characteristics provides the general principle of the thinking on human beings' behavior. After rigorous scientific testing, the model has been approved by the circle of personality psychology. FFM, also known as Big Five, is one kind of characteristic perspective. It is NEO-PI-R personality inventory developed by Costa \& McCrae (1992a). According to past literature, job satisfaction is relatively influenced by the employees' personality traits. Thus, this study treats internal auditors of firms as the subjects, and analyzes the personality traits of internal auditors' different statistical variables. Based on the research results, the suggestions are proposed for the reference of the business circle. 
Guilford (1959) suggested that personality is the combination of personal characteristics, attributes and properties. Thus, individuals have persistent and unique characteristics different from others. According to Smith \& Tyler (1997), the society includes the groups defined upon population and members are decided by personal bodies or social attributes. Demographic statistics reveal quality and characteristics which include personality traits and common psychological capabilities. It is the individual difference of psychological process and behavior (Brand, Egan, \& Deary, 1993).

Personality is the unique composition of personal characteristics, and it determines the interaction between human beings and environment. Personality also interacts with the situations. Allport $(1937,1961)$ suggested that personality is the dynamic organization in the individuals' psychological system and the unique form which determines a person's "adaption to external environment" and "thinking \& behavior". Therefore, the individuals' behavior reflects the unique personality characteristics. When the characteristics continuously appear in different situations, they are called personality traits. However, in the studies on personality traits, FFM is more commonly used and accepted by the scholars. In recent years, the psychologists have generalized a more proper theoretical framework to describe the employee difference in personnel matter arrangement. Tupes \& Christal (1961), Norman (1963) and other studies suggested that FFM is legitimate to be the classification criterion of personality construction. According to the literatures on personality, FFM can be the principle framework for the researchers. Mount \& Barrick (1995) suggested that FFM can be applied to personality measurement, particularly the selection of employees. Goldberg (1990) demonstrated the FFM framework of Norman. FFM of Costa \& McCrae (1992) is identified the most: agreeableness, conscientiousness, extraversion, neuroticism and experience openness.

\subsection{Research Purposes}

Based on research background and motivations above, this study intends to find the relationship between internal auditors' demographic variables and personality traits. The findings can serve as the references for the recruitment of internal auditors. The research purpose is to find if internal auditors' demographic variables have significant differences on personality traits. According to above research purpose and literature review, this study assumes that internal auditors' personality traits will be significantly different according to different demographic variables.

\section{Methods}

\subsection{Sample}

This study conducted a questionnaire survey on the internal auditors in the branches of four regions in the Institute of Internal Auditors, R.O.C., and distributed the questionnaires on site. A total of 567 questionnaires were distributed to the internal auditors who participated in the project lecture on the day of survey, and 376 copies were retrieved, with a return rate of $66 \%$. After eliminating 104 invalid samples, there were 272 valid samples, with a valid return rate of $48 \%$. 


\section{$2.2 \quad$ Instrument}

This study measured personality traits by NEO Five-Factor Inventory (NEO-FFI) developed by Costa \& McCrace (1992b), and adopted their Form S. After the revision, there were 35 items in this inventory. Cronbach's alpha of the dimensions is extraversion 0.7181 , agreeableness 0.6268 , neuroticism 0.7926 and conscientiousness 0.7343 .

\section{Results}

\subsection{Dimensions of Demographic Variables}

The sample structure is based on gender, age, education level, subordination level, job title and working years. Among the valid samples, $33.1 \%$ are males and $66.5 \%$ are females; most of them are 26 35 years old (45.6\%), followed by 36 45 years old $(39.0 \%), 46 \sim 55$ years old $(12.1 \%)$, above 55 years old $(2.6 \%)$ and below 25 years old $(0.4 \%)$. There are few subjects aged below 25 years old and above 55 years old, and thus, they are respectively allocated in " $26 \sim 35$ " and "46 55" and are revised as "below 35 " and "above 46". Regarding education level, most of the subjects are graduated from universities $(65.8 \%)$, followed by college (17.3\%), above master (14.7\%) and senior high school (vocational school) (1.8\%). Generally speaking, $80.5 \%$ subjects are at least graduated from universities. Since few samples are graduated below senior high schools (vocational schools), they are allocated in "college" and it is revised as below (including) college. As to subordination level of internal auditors, according to sample distribution, general manager (office) is the most $(50.4 \%)$, followed by president (office) (27.6\%) and the board of directors (12.9\%). Some do not belong to above $(8.1 \%)$ (such as vice general manager, financial unit, etc.). In terms of job title, basic auditors $(34.2 \%)$ are the most, followed by experienced auditors $(31.3 \%)$ and general auditors (19.5\%). Since job titles for internal auditors in different firms are varied, "others" are 14.7\%; in addition, as to total working years as internal auditors, "below 3 years" is the most (38.2\%), followed by "3 5 years" $(29.0 \%)$, "6 10 years" (23.9\%), "11 15 years $(4.8 \%)$ and above 16 years $(2.2 \%)$. Since there are few subjects above 16 years, they are allocated in "11 15 years" and revised as "above 11 years".

\subsection{Difference Analysis between Gender and Personality Traits}

Analysis is conducted to find if gender has a significant difference on four dimensions of personality traits. Independent sample t test is conducted on males and females to find if male and female internal auditors have a significant difference on the dimensions of personality traits. According to the findings, gender does not have a significant difference on dimensions of personality traits, indicating that internal auditors are not influenced by gender as a variable. Most of the valid samples are females, and this suggests that the firms prefer hiring the females. The analytical results do not indicate the difference, as shown in Table 1. 
Table 1. Differences between the various dimensions of gender in personality

\begin{tabular}{ccccccc}
\hline Variable & Gender & $\begin{array}{c}\text { Sample } \\
\text { Size }\end{array}$ & M & SD & t & p \\
\hline Extraversion & M & 90 & 3.6611 & .58337 & .127 & .722 \\
& F & 181 & 3.6961 & .54918 & & \\
Agreeableness & M & 90 & 3.8519 & .46234 & 1.901 & .169 \\
& F & 181 & 3.8131 & .43485 & & \\
Neuroticism & M & 90 & 2.5653 & .56533 & .317 & .574 \\
& F & 181 & 2.5311 & .59130 & & \\
Conscientiousness & M & 90 & 3.8386 & .46375 & .805 & .370 \\
& F & 181 & 3.9517 & .46668 & &
\end{tabular}

\subsection{Difference Analysis between Age, Education Level, Subordination Level, Job Title, Working Years and Personality Traits}

Analysis is conducted to find if age, education level, subordination level, job title and working years have significant differences on four dimensions of personality traits. One-way ANOVA is conducted on variables with at least two categories to find if there is significant difference among the groups of variables. Scheffe post hoc comparison is conducted on the groups with significant differences to compare the difference of pair groups.

According to Table 2, internal auditors are not influenced by education level in different variables. Among the subjects, most of them are graduated from universities $(65.8 \%)$, indicating that education level is a necessary condition for internal auditing; however, it is not the key factor of the variables. Internal auditors of different subordination levels do not show significant differences in the dimensions of personality traits, suggesting that internal auditors are not influenced by different subordination levels in the variables.

Job title has a significant difference on "conscientiousness" in personality traits. Scheffe post hoc comparison finds that "others" in conscientiousness is higher than entry-level auditors. However, "others" cannot be classified; thus, the analytical result cannot be indicated. In addition, according to one-way ANOVA, F value of job title on "extraversion" in personality traits is significant. However, Scheffe post hoc comparison does not show that the mean of any pair groups is significantly different. Although extraversion is different on the cognition of subordination level, it is uncertain if the supervisors or non-supervisors show a higher degree. Working years has a significant difference on "conscientiousness" in personality traits. Scheffe post hoc comparison finds that the degree of total working years for $6 \sim 10$ years is higher than total working years below 3 years. In other words, when internal auditors' working years are longer, their conscientiousness is stronger. In addition, one-way ANOVA finds that F value of working years on "extraversion" in personality traits is significant; however, Scheffe post hoc comparison does not show a significant difference of mean in any two groups. 
Mean and standard deviation of dimensions of personality traits are shown in Table 2. Regarding personality traits, average score of each item is 3.4369 and it is medium. Among the dimensions, the score of conscientiousness is the highest (mean =3.9164). It shows that internal auditors' characteristics of competency, responsibility, selfrequirement, carefulness, persistence and goal orientation are more significant. Score of neuroticism is the lowest (mean $=2.5409$ ). It means that internal auditors' neuroticism is insignificant, indicating that internal auditors should have the characteristics to be calm under the pressure.

Table 2. The demographic variables in the personality differences between the various dimensions

\begin{tabular}{|c|c|c|c|c|c|c|c|}
\hline Variable & & & $N$ & $M$ & $S D$ & $F$ & $\begin{array}{c}\text { Scheffe } \\
\text { Post hoc } \\
\text { compari- } \\
\text { son }\end{array}$ \\
\hline \multirow{18}{*}{$\begin{array}{l}\text { Extra- } \\
\text { version }\end{array}$} & \multirow[t]{3}{*}{ Age } & (1) under the age of 35 & 125 & 3.6560 & .59709 & \multirow[t]{3}{*}{.343} & \\
\hline & & (2) $36-45$ years old & 106 & 3.7005 & .51457 & & \\
\hline & & (3) More than 46 years old & 40 & 3.7313 & .56440 & & \\
\hline & \multirow{7}{*}{$\begin{array}{l}\text { Educa- } \\
\text { tion } \\
\text { level } \\
\text { Subor- } \\
\text { dination } \\
\text { level }\end{array}$} & (1) College below & 52 & 3.7548 & .40972 & \multirow[t]{3}{*}{.621} & \\
\hline & & (2) University & 179 & 3.6592 & .58040 & & \\
\hline & & (3) Master above & 40 & 3.7063 & .63521 & & \\
\hline & & (1) Board of directors & 35 & 3.7357 & .51429 & \multirow[t]{4}{*}{2.367} & \\
\hline & & (2) Chairman of the board & 75 & 3.5633 & .57992 & & \\
\hline & & (3) General Manager & 137 & 3.7591 & .56017 & & \\
\hline & & (4) Other & 22 & 3.5795 & .50819 & & \\
\hline & Job & (1) Chief Auditor & 53 & 3.7972 & .54609 & & n. s. \\
\hline & \multirow[t]{3}{*}{ Title } & (2) Senior auditor & 85 & 3.7676 & .51291 & \multirow[t]{3}{*}{$3.123 *$} & \\
\hline & & (3) Primary auditor & 93 & 3.5538 & .57678 & & \\
\hline & & (4) Other & 40 & 3.6625 & .58984 & & \\
\hline & \multirow{5}{*}{$\begin{array}{l}\text { Work- } \\
\text { ing } \\
\text { years }\end{array}$} & (1) less than three years & 104 & 3.6250 & .58397 & \multirow[t]{5}{*}{$3.906 * *$} & \multirow[t]{5}{*}{ n. s. } \\
\hline & & (2) $3-5$ years & 79 & 3.5886 & .57601 & & \\
\hline & & (3) $6-10$ years & 65 & 3.8192 & .49511 & & \\
\hline & & (4) More than 11 years & 19 & 3.9474 & .46082 & & \\
\hline Holistic & & & & 3.6847 & .55891 & & \\
\hline \multirow{18}{*}{$\begin{array}{l}\text { Agreea- } \\
\text { bleness }\end{array}$} & \multirow[t]{3}{*}{ Age } & (1) under the age of 35 & 125 & 3.7760 & .50184 & \multirow[t]{3}{*}{1.491} & \\
\hline & & (2) 36-45 years old & 106 & 3.8648 & .38566 & & \\
\hline & & (3) More than 46 years old & 40 & 3.8792 & .38302 & & \\
\hline & \multirow{7}{*}{$\begin{array}{l}\text { Educa- } \\
\text { tion } \\
\text { level } \\
\text { Subor- } \\
\text { dination } \\
\text { level }\end{array}$} & (1) College below & 52 & 3.8750 & .36436 & \multirow[t]{3}{*}{.396} & \\
\hline & & (2) University & 179 & 3.8156 & .45916 & & \\
\hline & & (3) Master above & 40 & 3.8083 & .47223 & & \\
\hline & & (1) Board of directors & 35 & 3.7333 & .35974 & \multirow[t]{4}{*}{1.182} & \\
\hline & & (2) Chairman of the board & 75 & 3.8000 & .37066 & & \\
\hline & & (3) General Manager & 137 & 3.8735 & .51032 & & \\
\hline & & (4) Other & 22 & 3.7879 & .28257 & & \\
\hline & Job & (1) Chief Auditor & 53 & 3.8648 & .44585 & \multirow[t]{4}{*}{1.473} & \\
\hline & \multirow[t]{3}{*}{ Title } & (2) Senior auditor & 85 & 3.8882 & .35485 & & \\
\hline & & (3) Primary auditor & 93 & 3.7581 & .52963 & & \\
\hline & & (4) Other & 40 & 3.8000 & .37780 & & \\
\hline & \multirow{5}{*}{$\begin{array}{l}\text { Work- } \\
\text { ing } \\
\text { years }\end{array}$} & (1) less than three years & 104 & 3.7981 & .43117 & \multirow[t]{5}{*}{1.367} & \\
\hline & & (2) $3-5$ years & 79 & 3.7785 & .49694 & & \\
\hline & & (3) $6-10$ years & 65 & 3.9179 & .40731 & & \\
\hline & & (4) More than 11 years & 19 & 3.8333 & .39675 & & \\
\hline Holistic & & & & 3.8272 & .44335 & & \\
\hline
\end{tabular}


Table 2. (continued)

\begin{tabular}{|c|c|c|c|c|c|c|c|}
\hline Variable & & & $N$ & $M$ & $S D$ & $F$ & $\begin{array}{l}\text { Scheffe } \\
\text { Post hoc } \\
\text { compari- } \\
\text { son }\end{array}$ \\
\hline \multirow{17}{*}{$\begin{array}{l}\text { Neuro- } \\
\text { ticism }\end{array}$} & \multirow[t]{2}{*}{ Age } & (1) under the age of 35 & 125 & 2.6050 & .66720 & \multirow[t]{2}{*}{1.755} & \\
\hline & & $\begin{array}{l}\text { (2) } 36-45 \text { years old } \\
\text { (3) More than } 46 \text { years old }\end{array}$ & $\begin{array}{l}106 \\
40\end{array}$ & $\begin{array}{l}2.4623 \\
2.5594\end{array}$ & .43032 & & \\
\hline & Educa- & $\begin{array}{l}\text { (1) College below } \\
\text { lat }\end{array}$ & 52 & 2.6130 & .60292 & \multirow[t]{3}{*}{.789} & \\
\hline & tion & (2) University & 179 & 2.5405 & .59781 & & \\
\hline & level & (3) Master above & 40 & 2.4594 & .47399 & & \\
\hline & Subor- & (1) Board of directors & 35 & 2.4893 & .51034 & \multirow[t]{4}{*}{1.147} & \\
\hline & dination & (2) Chairman of the board & 75 & 2.6200 & .60349 & & \\
\hline & \multirow[t]{2}{*}{ level } & (3) General Manager & 137 & 2.5365 & .59682 & & \\
\hline & & (4) Other & 22 & 2.3750 & .52893 & & \\
\hline & Job & (1) Chief Auditor & 53 & 2.5566 & .51862 & \multirow[t]{4}{*}{.994} & \\
\hline & \multirow[t]{3}{*}{ Title } & (2) Senior auditor & 85 & 2.5206 & .52605 & & \\
\hline & & (3) Primary auditor & 93 & 2.6062 & .63362 & & \\
\hline & & (4) Other & 40 & 2.4219 & .64592 & & \\
\hline & Work- & (1) less than three years & 104 & 2.5793 & .60114 & \multirow[t]{5}{*}{1.722} & \\
\hline & ing & (2) 3-5 years & 79 & 2.5997 & .60625 & & \\
\hline & \multirow[t]{3}{*}{ years } & (3) $6-10$ years & 65 & 2.4000 & .53728 & & \\
\hline & & (4) More than 11 years & 19 & 2.5132 & .44467 & & \\
\hline \multirow{19}{*}{$\begin{array}{l}\text { Holistic } \\
\text { Con- } \\
\text { scien- } \\
\text { tious- } \\
\text { ness }\end{array}$} & & & & 2.5409 & .58146 & & \\
\hline & \multirow{3}{*}{ Age } & (1) under the age of 35 & 125 & 3.8510 & .51994 & \multirow[t]{3}{*}{2.286} & \\
\hline & & (2) $36-45$ years old & 106 & 3.9788 & .41529 & & \\
\hline & & (3) More than 46 years old & 40 & 3.9625 & .40252 & & \\
\hline & Educa- & (1) College below & 52 & 4.0120 & .41440 & \multirow[t]{3}{*}{1.423} & \\
\hline & tion & (2) University & 47 & 4.0426 & .41725 & & \\
\hline & level & (3) Master above & 40 & 3.9250 & .38998 & & \\
\hline & \multirow{5}{*}{$\begin{array}{l}\text { Subor- } \\
\text { dination } \\
\text { level }\end{array}$} & (1) Board of directors & 35 & 3.9607 & .44014 & \multirow[t]{4}{*}{.856} & \\
\hline & & (2) Chairman of the board & 75 & 3.8633 & .42523 & & \\
\hline & & (3) General Manager & 137 & 3.9124 & .51122 & & \\
\hline & & (4) Other & 22 & 4.0284 & .30602 & & \\
\hline & & (1) Chief Auditor & 53 & 3.9410 & .45836 & $3.567^{*}$ & (4)>(3) \\
\hline & Job & (2) Senior auditor & 85 & 3.9559 & .39420 & & \\
\hline & \multirow{2}{*}{ Title } & (3) Primary auditor & 93 & 3.8038 & .51453 & & \\
\hline & & (4) Other & 40 & 4.0688 & .46336 & \multirow{5}{*}{$3.450^{*}$} & \multirow{5}{*}{ (3)>(1) } \\
\hline & & (1) less than three years & 104 & 3.8666 & .46617 & & \\
\hline & Work- & (2) $3-5$ years & 79 & 3.8671 & .49531 & & \\
\hline & ing & (3) $6-10$ years & 65 & 4.0731 & .41156 & & \\
\hline & years & (4) More than 11 years & 19 & 3.8289 & .42738 & & \\
\hline Holistic & & & & 3.9164 & .46686 & & \\
\hline
\end{tabular}

\section{Discussion}

The results showed that job title has a significant difference on extraversion and conscientiousness in personality traits; total working years has a significant difference on extraversion and conscientiousness in personality traits; job title and total working years have significant differences on conscientiousness in internal auditors' personality traits. Internal auditors with total working years above 6-10 years have the strongest conscientiousness. In other words, internal auditors' conscientiousness varies according to working years. The auditors with longer working years have stronger conscientiousness.

In business operation and management, the role of internal auditing will become more important and influential. In the future, the firms will value the function and benefits of internal auditing, thus making internal auditors' personality traits a critical factor in the recruitment process, so that they could fulfill the important and effective roles. 
This study suggests that when selecting internal auditors, the firms can use various "personality traits evaluation scales". They should select internal auditors with personality traits such as "extraversion", "agreeableness" and "conscientiousness". These auditors are more competent, they enjoy internal auditing and will have higher job performance.

The findings show that internal auditors having total working years less than 3 years account for the majority (38.2\%), indicating that their turnover rate is high. Holland (1985) found that when personality traits match the jobs, the employees will have the highest job satisfaction and work efficiency, as well as the lowest turnover rate.

Therefore, it is suggested that senior managers should value internal auditors' job satisfaction, identify the problems, and improve them by proper measures in order to reduce the turnover of internal auditors and ensure that they can function properly in the organizations, enjoy the work, and contribute to the firms.

\section{References}

1. Allport, G.W.: Personality: A Psychological Interpretation. Holt, Rinehart, \& Winston, New York (1937)

2. Allport, G.W.: Pattern and Growth in Personality. Holt, Rinehart \& Winston, New York (1961)

3. Brand, C.R., Egan, V., Deary, I.J.: Personality and general intelligence. In: Bonaiuto, P., van Heck, G.L., Nowack, W., Deary, I.J. (eds.) Personality Psychology in Europe, vol. 4, Tilburg University Press, Tilburg (1993)

4. Costa Jr., P.T., McCrae, R.R.: Four Ways Five Factors are Basic. Personality and Individual Differences 13, 653-665 (1992a)

5. Costa Jr., P.T., McCrae, R.R.: Professional Manual for The NEO PI-R and NEO-FFI. Psychological Assessment Resources, Inc., Odessa (1992b)

6. Goldberg, L.R.: An Alternative Description of Personality: The Big Five Factor Structure. Journal of Personality and Social Psychology 59, 1216-1229 (1990)

7. Guilford, J.P.: Personality. McGraw-Hill, New York (1959)

8. Holland, J.L.: Making Vocational Choices: A Theory of Vocational Personalities and Work Environments. Prentice-Hall, Englewood Cliffs (1985)

9. Mount, M.K., Barrick, M.R.: The Big Five Personality Dimensions: Implications for Research and Practice in Human Resources Management. In: Ferris, G.R. (ed.) Research in Personnel and Human Resources Management, vol. 13, pp. 153-200. JAI Press, Greenwich (1995)

10. Norman, W.T.: Toward and Adequate Taxonomy of Personality Attributes: Replicated Factor Structure. Journal of Abnormal and Social Psychology 66, 574-583 (1963)

11. Smith, H.J., Tyler, T.R.: Choosing the right pond: the impact of group membership on self-esteem and group-oriented behaviors. Journal of Experimental Social Psychology 33, 146-170 (1997)

12. Tupes, E.C., Christal, R.E.: Recurrent Personality Factors Based on Trait Ratings. Journal of Personality 60, 225-251 (1961) 